\title{
Electroacupuncture: A New Approach for Improved Postoperative Sleep Quality After General Anesthesia
}

This article was published in the following Dove Press journal: Nature and Science of Sleep

Man Luo $\mathbb{D}^{1, *}$
Bijia Song
Junchao Zhu'

'Department of Anesthesiology, Shengjing Hospital of China Medical University, Shenyang, Liaoning, People's Republic of China; ${ }^{2}$ Department of Anesthesiology, Friendship Hospital of Capital Medical University, Beijing, People's Republic of China

*These authors contributed equally to this work
Correspondence: Junchao Zhu Department of Anesthesiology, Shengjing Hospital of China Medical University, Shenyang, Liaoning, People's Republic of China

Email zhujunchaol@hotmail.com

\begin{abstract}
General anesthesia produces a state of drug-induced unconsciousness that is controlled by the extent and duration of administered agents. Whether inhalation or intravenous in formulation, such agents may interfere with normal sleep-wake cycles, impairing postoperative sleep quality and creating complications. Electroacupuncture is a new approach widely applied in clinical practice during recent years. This particular technology helps regulate neurotransmitter concentrations in the brain, lowering norepinephrine and dopamine levels to improve sleep quality. It also alleviates surgical pain that degrades postoperative sleep quality after general anesthesia by downregulating immune activity (SP, NK-1, and COX-1) and upregulating serotonin receptor (5-HT1AR, 5-HT2AR) and endocannabinoid expression levels. However, large-scale, multicenter studies are still needed to determine the optimal duration, frequency, and timing of electroacupuncture for such use.
\end{abstract}

Keywords: general anesthesia, sleep quality, acupoints, electroacupuncture

\section{Introduction}

General anesthesia is an independent risk factor for circadian rhythm desynchronization, which subsequently alters the structure and quality of postoperative sleep. ${ }^{1,2}$ Resultant changes in sleep quality include insomnia, hypersomnia, parasomnia, and sleep-related breathing disorders. Affected patients may demonstrate polysomnographic evidence of severe sleep deprivation or sleep fragmentation, as well as a lowering/loss of slow-wave sleep (SWS) and rapid eye movement (REM) sleep. ${ }^{3,4}$ They may also report diminished sleep time, more episodic awakening, reduced sleep quality, and frequent nightmares. ${ }^{5}$ Disturbances of this sort increase the incidence of postoperative complications, including postoperative fatigue, severe anxiety and depression, cardiovascular events, and pain sensitivity. ${ }^{6,7}$ Long-term use of drugs to treat sleep disorders may lead to addiction and truncation, so their clinical utility is limited. ${ }^{8}$

Acupuncture has been a mainstay of Chinese health care for at least 2500 years, calling for the insertion of fine needles at specific acupoints. Bodily balance is thereby achieved and physiologic functions restored, without impacting natural sleep-wake cycles. ${ }^{9}$ Acupuncture may actually improve sleep quality by increasing serotonin and aminobutyric acid levels, reducing glutamate levels via stimulatory means, ${ }^{10,11}$ and eliciting sedative effects that preempt the use of hypnotics. ${ }^{12}$

Electroacupuncture is a new method of acupuncture that has gained wide clinical acceptance in recent years. It involves the provocation and adjustment of 
meridians and collaterals, applying micropulse current (akin to human bioelectricity) at specific acupoints for desired sensations. Electroacupuncture has been invoked for a variety clinical symptoms, including primary insomnia. The mechanisms entailed are fundamentally safe and effective for this purpose, capable of promoting quality sleep through direct autonomic nervous manipulation. ${ }^{13}$ The present discussion addresses changes in sleep quality following general anesthesia, as well as mechanisms by which electroacupuncture improves quality of sleep and mitigates complications postoperatively.

\section{Changes in Sleep Quality After General Anesthesia \\ Natural Sleep Pathway and Sleep Mechanisms Under General Anesthesia}

In humans, the spontaneous sleep-wake cycle is a recursive organization involving two distinctive states, namely nonREM (NREM) and REM sleep. NREM sleep is further divisible into stages N1, N2, and N3, the latter being SWS. REM sleep accounts for $20-25 \%$ of total sleep in adults. ${ }^{14}$ Various nerve centers, neurotransmitters, and endogenous sleep- or wake-related substances are involved in and seemingly drive the sleep-wake cycle. ${ }^{15}$ The ventrolateral preoptic nucleus (VLPO) of the hypothalamus, a key area for sleep promotion, is chiefly composed of GABAergic neurons. The VLPO promotes sleep by inhibiting GABA synapses in the basal forebrain, hypothalamus, and brain stem, ${ }^{16}$ whereas the nodal papillary nucleus and locus coeruleus are pivotal in driving cortical excitability and sobriety via norepinephrine release, their fibers coursing through the ascending reticular system. Ultimately, the sleep-arousal transition is achieved through active and rhythmic central nervous system (CNS) regulation. ${ }^{17}$

General anesthesia produces drug-induced states of unconsciousness. Such states are nonphysiologic and are not readily subject to environmental flux. They differ from natural sleep and are largely controlled by the extent and the duration of administered anesthetics. Given the array of agent-specific clinical differences, general anesthesia is hardly a singular phenomenon, instead representing an aggregate of the following discrete clinical endpoints: hypnosis (unawareness of one's environment), analgesia (lack of pain sensitivity), amnesia (loss of memory), and immobility after surgical stimulation. ${ }^{18}$ Recent studies have discovered some commonality of mechanisms regulating general anesthesia and sleep. ${ }^{7,19}$ There are behavioral similarities between sleep and anesthesia that may be linked to intracellular GABA levels within the brain. Bjornstrom and Eintrei have reported that GABA is involved in negatively regulating neuronal activity (eg, sleep), and most general anesthetics are known to be GABA agonists. ${ }^{20}$ General anesthetics such as propofol and thiopental sodium induce sedation, hypnotization, and disappearance of consciousness by enhancing GABA neuronal activity in the VLPO and inhibiting nodal papillary nuclei and locus coeruleus. ${ }^{21-23}$

\section{Effects of Various General Anesthetics on Postoperative Sleep Quality}

Both inhalation and intravenous agents used as general anesthetics may interfere with normal sleep-wake cycles, causing melatonin disorders and affecting circadian clock genes, including period (PER), cryptochromes (CRY), $C L O C K$, and BMAL1, situated within suprachiasmatic nucleus. ${ }^{24,25}$ Exposure to volatile general anesthetics, such as sevoflurane, isoflurane, and halothane, may cause shortterm sleep disturbances and fragmentation. Use of isoflurane anesthesia during abdominal surgery seems to suppress SWS and nearly eliminate REM sleep on the first postoperative night, although this gradually abates, surpassing preoperative levels and intensifying. ${ }^{26}$ Sevoflurane inhalation may induce REM sleep deficits, delayed REM sleep recovery, and decreased latency to REM sleep, without affecting wakefulness or nonREM sleep. ${ }^{27}$

Melatonin is an important neuroendocrine hormone that maintains the circadian rhythm and regulates sleepwake cycles. ${ }^{28}$ Cronin et al have shown that inhalation anesthesia delivered for gynecologic surgical procedures reduces nocturnal melatonin levels on the first (vs second or third) postoperative night, returning to baseline levels after the third night. ${ }^{29}$ In adults undergoing cardiac surgery, intravenous anesthesia also seems to lower melatonin secretion on the night after its use. ${ }^{30}$ Depending on perioperative concentration, secretion rhythm, and peak secretion, such changes may trigger sleep-wake cycle disorders, postoperative delirium, or cognitive dysfunction. ${ }^{28,31-33}$

\section{Consequences of Changes in Sleep Quality After General Anesthesia}

General anesthesia is known to diminish postoperative sleep quality. Structural and quality disturbances in postoperative sleep consequently heighten the incidence of postoperative complications (eg, delirium, ${ }^{34}$ cognitive impairment, ${ }^{35}$ cardiovascular adverse events, ${ }^{36,37}$ immune hypofunction, etc). 


\section{Impact of Altered Sleep Quality on Cognition and Memory}

Diminished postoperative sleep quality may incite inflammation, which bears a relation with hippocampal-dependent memory impairment and disturbed cognition. ${ }^{38-40}$ Outcomes of a study by Gögenur et al have indicated a higher prevalence of sleep disturbance and more pronounced physiologic stress may figure prominently in the development of postoperative cognitive impairment by patients submitting to major abdominal surgery. ${ }^{41}$ A normal sleep pattern is important for intact cognitive abilities. Even brief sleep pattern disturbances or voids of REM sleep during first or second postoperative night may contribute to early postoperative cognitive decline. ${ }^{42}$

Certain inflammatory mediators have been implicated in sleep and cognitive disturbances during the postoperative period. Kapsimalis et al have attributed impaired sleep and cognitive function to postsurgical cytokines (IL-1, IL-6) released in response to inflammatory stress. ${ }^{43}$ Sleep deprivation after sevoflurane inhalation may also boost hippocampal expression of inflammatory factors IL-1 $\beta$ and IL-6. Reduced REM and SWS and increased fatigue have been produced by administering IL- $6,{ }^{44}$ and increases in IL-6 concentration have been shown to degrade cognitive function. ${ }^{45}$ It appears that increased IL-1 $\beta$ levels damage neuronal membranes via lipid peroxidation, serving to reduce memory and learning. ${ }^{46}$

Acute sleep loss similarly induces transcriptional alterations in circadian clock genes, such as BMAL1, CLOCK, $C R Y 1$, and PERl, that further aggravate cognitive impairment. ${ }^{47}$ In an animal model, Hou et al determined that sleep deprivation inhibited hippocampal Bmall and Egr1 expression levels for more than seven days after sevoflurane inhalation, worsening pathogenically impaired pyramidal neurons, promoting activation of CA1 astrocytes, and significantly reducing cognitive levels (learning and memory especially). ${ }^{48}$ In addition, there is clinical trial evidence linking lower intracellular magnesium concentrations to sleep-related cognitive and memory dysfunction. ${ }^{49} \mathrm{It}$ may well be that magnesium upregulates levels of NR2Bcontaining N-methyl-D-aspartate (NMDA) receptors critical for synaptic plasticity and memory. ${ }^{50}$

\section{Impact of Altered Sleep Quality on Cardiovascular and Nervous Systems}

Postoperative lapses in sleep quality are risk factors for both cardio- and cerebrovascular diseases, including a predisposition to thrombotic events and arrhythmias. ${ }^{51}$ One prospective cohort study $(\mathrm{N}=388)$ assessing patient status after percutaneous coronary intervention has demonstrated an association between aggregate symptoms of poor sleep and occurrences of major cardiac events, including myocardial infarction, repeat revascularization, and cardiac death. ${ }^{52}$ Another study has also confirmed that the biologic CLOCK gene is widely expressed in both cardio- and cerebrovascular systems, exerting important regulatory control of heart rate, myocardial growth, cardiac triglycerides, glycogen metabolism, and contractility. ${ }^{53}$ The pathogenesis of cardiovascular disease may, therefore, involve sleep deprivation-induced desynchronization of the cardiomyocyte circadian clock. ${ }^{54,55}$

By infringing on sleep-wake rhythms, general anesthesia treads on a major source of sleep disorders, threatening to disrupt the endogenous circadian clock. ${ }^{24}$ Ohe et al have demonstrated that sevoflurane increases levels NAD+, thus suppressing mPer2 expression. ${ }^{56}$ According to Viswambharan et al, ${ }^{57}$ the Per2 circadian clock gene is critical for maintaining normal cardiovascular function. In mutations of Per2, nitrous oxide (NO) and prostacyclin levels secreted by arterial endothelium are reduced, whereas prostaglandin release, endodermal dysfunction, and the potential for thrombosis are heightened, predisposing to cardio- and cerebrovascular pathology. Disorders of circadian rhythm imposed by general anesthetics may impact patient prognosis through similar means. Ma et al have determined potential biomarkers of sleep disorders, having identified altered expression levels of four proteins (PKM, CLU, KNG1, and PFN1) in sleepdeprived rats. ${ }^{58}$ Their findings indicate that high-level expression of KNG1, PFN1, and PKM due to sleep deprivation may increase risks of cardiocerebrovascular and neuronal diseases in a rat model. However, CLU exerts a neuroprotective effect by preventing excessive inflammation, inhibiting activation of complement, and enabling clearance of systemic debris. Reduced expression of CLU in conjunction with sleep deprivation may undermine normal cardiovascular and nervous system functions.

\section{Electroacupuncture Alleviates Postoperative Complications that Affect Sleep Quality After General Anesthesia}

General anesthetics diminish postoperative sleep quality, as do the postoperative complications of general anesthesia. The reported benefits of electroacupuncture include substantial analgesic and sedative properties, enhanced immune function, and fewer postoperative complications (ie, pain, nausea, and vomiting) due to diminished postoperative 
sleep quality. ${ }^{15,59}$ These are achieved through comprehensive coordination of multiple targets, levels, links, and pathways. ${ }^{60,61}$ The specific effects exerted at various acupoints are listed in Table 1.

\section{Mechanisms of Electroacupuncture in Treating Postoperative Pain}

Pain caused by surgical trauma is often a considerable challenge for caregivers. Following surgery, 49 74.3\% of patients experience moderate or severe levels of pain. ${ }^{62}$ However, there is a reciprocal relationship between pain and and sleep. The pain itself disrupts sleep quality, which in turn intensifies pain sensitivity. ${ }^{63}$ Although pharmacologic agents administered as epidural, intraspinal, or intrapleural anesthesia, or as patient controlled analgesia (PCA) provide effective postoperative pain relief in most instances, analgesic drugs (especially opioids) are associated with drowsiness, respiratory depression, and sleep disruption. Reduced SWS, dose-dependent REM suppression, variability in total sleep time, and awakening or arousal episodes during sleep may be problematic. ${ }^{64,65}$

Experimental use of electroacupuncture in humans has served to increase pain thresholds by $\sim 20-30 \% .{ }^{66} \mathrm{In}$ a study by Sim et al, electroacupuncture at PC-6 (Neiguan), ST-36 (Zusanli) bilaterally, and subcutaneously along skin incisions proved superior to sham attempts in relieving postoperative abdominal pain, as measured by morphine intake $6-12 \mathrm{~h}$ after surgical procedures. ${ }^{67}$ Zeng et al also found acupuncture better than oral morphine sulphate in analgesic effect, defined as total pain remission by Visual Analog Scale (VAS) at two, four, and six hours postoperatively. ${ }^{68}$ White et al applied electroacupuncture to ST-36 (Zusanli) and LI-4 (Hegu) acupoints at low $(2 \mathrm{~Hz})$ and high $(100 \mathrm{~Hz})$ frequencies, determining that a combination of low- and high-frequency stimulation released various opioid peptides to synergistically improve postoperative pain and sleep quality. ${ }^{69}$ Low-frequency disperse-dense wave stimulation helps induce relaxation and relieve stress, whereas high-frequency sparse-dense wave stimulation exerts strong opioid- and nonopioid-mediated analgesic effects on the spinal cord. This effectively reduces postoperative analgesic use, accelerating surgical recovery and outcomes. ${ }^{70}$

Animal studies focused on mechanisms of electroacupuncture analgesia have established the following: (1) electroacupuncture at LI18 (Futu) in rats relieves acute incisional neck pain, showing an association with downregulation of immune activity (SP, NK-1, and COX-1) and upregulation 5-HT1AR and 5-HT2AR expression levels in dorsal horns of the spine; ${ }^{71}$ (2) electroacupunctureupregulated endocannabinoid seems to directly inhibit pain in a rat model, because CB2 receptor activation inhibits sensory nerve activities, ${ }^{72}$ and (3) electroacupuncture at PC6 (Neiguan) to LI4 (Hegu) may alter phosphorylation of the NMDA receptor NR2B subunit in C1-C3 segments of spinal cord, upregulating expression levels of 5-HT2AR mRNA and protein. ${ }^{73,74}$

\section{Mechanisms of Electroacupuncture in Restoring Postoperative Sleep Quality}

Patients often develop significant sleep disturbances immediately after surgery, especially if major procedures are involved. Typical polysomnographic manifestations include severe sleep deprivation, sleep fragmentation, or postoperative insomnia. ${ }^{75}$ Ye et al have recorded postoperative sleep disorders in $49.00-74.29 \%$ of patients with breast cancer. In this scenario, acupuncture at SI9 (Jianzhen) and GB21 (Jianjing) points may actually improve postoperative sleep quality. ${ }^{76}$ Xiao et al examined the effects of electroacupuncture on insomnia at various times, discovering that subjective sleep scores and sleep quality improved more decisively in subjects treated between 8:00 and 9:00 PM. $^{77}$ A randomized controlled study conducted by Xia et al revealed that acupuncture at GV20 (Baihui) may effectively improve hemorheology indices, promote recovery of brain tissue cells, relieve depression and anxiety, and enhance the postoperative sleep quality of patients after resection of thyroid cancers. ${ }^{78}$ Clinical studies have also reported that diminished postoperative sleep quality is common in patients undergoing total hysterectomy. Acupuncture at GV29 (Yintang), ST36 (Zusanli), SP6 (Sanyinjiao), and auricular points may improve the quality and efficiency of postoperative sleep and prolong its duration. ${ }^{79,80}$

Electroacupuncture not only regulates various mechanisms in the body to augment postoperative sleep quality, it also offers good sedation. Dense waves in particular relieve stress and suppress the CNS. There are several mechanisms by which acupuncture may remedy declining postoperative sleep quality. One is by regulating concentrations of 5-HT, norepinephrine, cortisol, melatonin, and other endogenous substances that indirectly influence sleep quality. Studies based on a rat model of insomnia have shown that electroacupuncture may restore normal levels of neurotransmitters (eg, 5-HT and 5-HIAA), IL-1 $\beta$, and tumor necrosis factor (TNF) and lower levels of norepinephrine and dopamine in 
Table I The Effect of Electroacupuncture at Different Acupoints

\begin{tabular}{|c|c|c|c|c|c|}
\hline Benefits & Classification & Mechanisms & $\begin{array}{l}\text { Acupuncture } \\
\text { Sites }\end{array}$ & $\begin{array}{l}\text { Acupuncture } \\
\text { Intervention }\end{array}$ & References \\
\hline \multirow[t]{4}{*}{$\begin{array}{l}\text { Alleviate pain } \\
\text { and improve } \\
\text { sleep quality }\end{array}$} & \multirow[t]{2}{*}{ Clinical trials } & (i) Increase the pain threshold. & $\begin{array}{l}\text { Neiguan (PC- } \\
\text { 6), Zusanli (ST- } \\
\text { 36), and the } \\
\text { points along } \\
\text { skin incision }\end{array}$ & $\begin{array}{l}\text { After pain scoring, } \\
\text { acupuncture for six hours }\end{array}$ & Zeng et $\mathrm{a}^{68}$ \\
\hline & & $\begin{array}{l}\text { (i) Low frequency discrete dense wave } \\
\text { stimulation induce the relaxation of nerve } \\
\text { stress. } \\
\text { (ii) High frequency sparse dense wave } \\
\text { stimulation has a strong opioid and non } \\
\text { opioid mediated analgesic effect on the } \\
\text { spinal cord. } \\
\text { (iii) The combination of low frequency and } \\
\text { high frequency electroacupuncture } \\
\text { stimulation will release a variety of opioid } \\
\text { peptides, which has a synergistic effect of } \\
\text { inhibiting pain. }\end{array}$ & $\begin{array}{l}\text { Zusanli (ST-36), } \\
\text { Hegu (LI-4) }\end{array}$ & $\begin{array}{l}\text { EA, Low frequency: } 2 \mathrm{~Hz} \\
\text { High frequency: } 100 \mathrm{~Hz}\end{array}$ & $\begin{array}{l}\text { White } \\
\text { et al }{ }^{69}\end{array}$ \\
\hline & \multirow[t]{2}{*}{$\begin{array}{l}\text { Animal } \\
\text { experimental } \\
\text { studies }\end{array}$} & $\begin{array}{l}\text { (i) Downregulate the immune activity of SP, } \\
\text { NK-I and COX-I } \\
\text { (ii) Upregulate the expression of 5-HTIAR } \\
\text { and 5-HT2AR in spinal dorsal horn. }\end{array}$ & $\begin{array}{l}\text { Futu (LII8), } \\
\text { Zusanli (ST36), } \\
\text { Yanglingquan } \\
\text { (GB34) }\end{array}$ & $\begin{array}{l}\text { EA on both sides of } \\
\text { acupoints for } 30 \mathrm{~min}, 2 \mathrm{~Hz} / \\
15 \mathrm{~Hz}, \mathrm{I} \mathrm{mA} \text { in the first } 15 \\
\text { min and } 2 \mathrm{~mA} \text { in the latter } \\
15 \mathrm{~min} .\end{array}$ & Qiao et $\mathrm{al}^{71}$ \\
\hline & & $\begin{array}{l}\text { (i) The change of phosphorylation level of } \\
\text { NR2B subunit of NMDA receptor in } \mathrm{Cl} \text { - } \\
\text { C3 segment of spinal cord. }\end{array}$ & $\begin{array}{l}\text { Neigen (PC-6), } \\
\text { Hegu (LI4), } \\
\text { Futu (LII8), } \\
\text { Zusanli (ST36), } \\
\text { Yanglingquan } \\
\text { (GB34) }\end{array}$ & $\begin{array}{l}\mathrm{EA}, 2 \mathrm{~Hz} / 100 \mathrm{~Hz}, \mathrm{I} \mathrm{mA}, 30 \\
\min \end{array}$ & Gao et al ${ }^{74}$ \\
\hline \multirow[t]{3}{*}{$\begin{array}{l}\text { Improve } \\
\text { insomnia }\end{array}$} & \multirow[t]{3}{*}{ Clinical trials } & \multirow[t]{2}{*}{$\begin{array}{l}\text { (i) Improve the sleep quality, prolong the } \\
\text { sleep time and improve the sleep } \\
\text { efficiency. }\end{array}$} & $\begin{array}{l}\text { Jianzhen (SI9), } \\
\text { Jianjing (GB2I), } \\
\text { Quchi (LIII), } \\
\text { Shousanli } \\
\text { (LIIO), Hegu } \\
\text { (LI4) }\end{array}$ & $\begin{array}{l}\text { Each acupoint was } \\
\text { massaged for three to five } \\
\text { minutes at a frequency of } \\
30 \text { times per minute, once } \\
\text { in the morning and one in } \\
\text { the evening }\end{array}$ & Ye et $\mathrm{al}^{76}$ \\
\hline & & & $\begin{array}{l}\text { Yintang } \\
\text { (GV29), Zusanli } \\
\text { (ST36), } \\
\text { Sanyinjiao (SP6) }\end{array}$ & $\begin{array}{l}\text { Intradermal needle, three } \\
\text { days }\end{array}$ & Qin et $\mathrm{al}^{79}$ \\
\hline & & $\begin{array}{l}\text { (i) Effectively improve hemorheology } \\
\text { indexes, promote the recovery of brain } \\
\text { cells, relieve depression and anxiety, and } \\
\text { improve the sleep quality of patients. }\end{array}$ & Baihui (GV20) & $\begin{array}{l}\text { Mild moxibustion, once } \\
\text { a day, } 20 \text { minutes each } \\
\text { time, seven days }\end{array}$ & Xia et $\mathrm{al}^{78}$ \\
\hline
\end{tabular}

(Continued) 
Table I (Continued).

\begin{tabular}{|c|c|c|c|c|c|}
\hline Benefits & Classification & Mechanisms & $\begin{array}{l}\text { Acupuncture } \\
\text { Sites }\end{array}$ & $\begin{array}{l}\text { Acupuncture } \\
\text { Intervention }\end{array}$ & References \\
\hline & \multirow[t]{3}{*}{$\begin{array}{l}\text { Animal } \\
\text { experimental } \\
\text { studies }\end{array}$} & $\begin{array}{l}\text { (i) Restore the normal levels of } \\
\text { neurotransmitters (such as 5-HT and } \\
5-\mathrm{HIAA} \text { ), IL-I } \beta \text { and TNF, and reduce the } \\
\text { levels of noradrenaline and dopamine in } \\
\text { the brain. } \\
\text { (ii) The expression of AMPK protein is } \\
\text { decreased, the levels of AC COA and Na } \\
+-\mathrm{K}+- \text { ATPase and plasma } \\
\text { corticosterone are increased. }\end{array}$ & $\begin{array}{l}\text { Shenmen } \\
\text { (HT7), } \\
\text { Sanyinjiao (SP6) }\end{array}$ & $\begin{array}{l}\mathrm{EA} \text {, density wave, } 5 \mathrm{~Hz} / \\
25 \mathrm{~Hz} \text {, needle retaining for } \\
15 \text { minutes, once a day for } \\
\text { five days }\end{array}$ & Zhu et $\mathrm{al}^{83}$ \\
\hline & & $\begin{array}{l}\text { (i) Increase the expression of mirl46a and } \\
\text { negatively regulate the Toll-like receptor } \\
\text { four signaling pathway, it can stably affect } \\
\text { the electrical activity of brain through } \\
\text { EEG biofeedback, thus effectively reduce } \\
\text { the neural stress function and play } \\
\text { sedation and hypnosis effects. }\end{array}$ & Zusanli (ST36) & $\begin{array}{l}\mathrm{EA} \text {, density wave, } 5 \mathrm{~Hz} / \\
100 \mathrm{~Hz}, 1.0 \mathrm{~mA} \text {, lasted for } \\
30 \text { minutes, once a day for } \\
\text { five days }\end{array}$ & Yang et $\mathrm{al}{ }^{84}$ \\
\hline & & $\begin{array}{l}\text { (i) Enhance the local blood circulation, } \\
\text { improve the cerebral ischemia, reduce the } \\
\text { level of plasma noradrenaline and } \\
\text { dopamine. }\end{array}$ & $\begin{array}{l}\text { Shenmen } \\
\text { (HT7), } \\
\text { Sanyinjiao (SP6) }\end{array}$ & $\begin{array}{l}\mathrm{EA} \text {, density wave, } 4 \mathrm{~Hz} / 60 \\
\mathrm{~Hz}, \mathrm{I} \mathrm{mA} \text {, needle retaining } \\
\text { for } 15 \text { minutes, once a day } \\
\text { for four days }\end{array}$ & $\begin{array}{l}\text { Cheng } \\
\text { et } \mathrm{al}^{82}\end{array}$ \\
\hline \multirow[t]{4}{*}{$\begin{array}{l}\text { Reduce } \\
\text { complications } \\
\text { affecting sleep } \\
\text { quality }\end{array}$} & \multirow[t]{2}{*}{ Clinical trials } & $\begin{array}{l}\text { (i) Effectively relieve the adverse flow of } \mathrm{Qi} \text {, } \\
\text { regulate the digestive system, and help } \\
\text { relax the gastrointestinal tract. }\end{array}$ & Neiguan (PC-6) & $\begin{array}{l}\mathrm{EA}, 2-100 \mathrm{~Hz} \text {, alternating } \\
\text { wave, not less than } 30 \\
\text { minutes, not more than } 60 \\
\text { minutes }\end{array}$ & Gan et $\mathrm{al}^{93}$ \\
\hline & & $\begin{array}{l}\text { (i) Concurrent stimulation of different points } \\
\text { may produce synergistic effect on } \\
\text { regulating gastrointestinal function } \\
\text { impacted by the surgery and anesthetics } \\
\text { to prevent PONV as well as accelerating } \\
\text { motility of the gastrointestinal track. }\end{array}$ & $\begin{array}{l}\text { Neiguan (PC- } \\
\text { 6), Hegu (LI4) }\end{array}$ & $\begin{array}{l}\text { Continuous acupuncture } \\
\text { during operation }\end{array}$ & $\begin{array}{l}\text { Alizadeh } \\
\text { et } \mathrm{al}^{92}\end{array}$ \\
\hline & \multirow[t]{2}{*}{$\begin{array}{l}\text { Animal } \\
\text { experimental } \\
\text { studies }\end{array}$} & $\begin{array}{l}\text { (i) Improve colonic transit by restraint stress } \\
\text { via corticotropin-releasing factor (CRF) } \\
\text { type-I receptors. } \\
\text { (ii) Delayed gastric emptying is alleviated by } \\
\text { CRF type-2 receptor, which mediates } \\
\text { parasympathetic efferent pathway. }\end{array}$ & $\begin{array}{l}\text { Zusanli (ST-36), } \\
\text { Tianshu (ST- } \\
\text { 25). }\end{array}$ & $\mathrm{EA}, \mathrm{I}-100 \mathrm{~Hz}$ & $\begin{array}{l}\text { Takahashi } \\
\text { et } \mathrm{al}^{97}\end{array}$ \\
\hline & & $\begin{array}{l}\text { (i) Evoke upregulation of hypothalamic } \\
\text { oxytocin (OXT) and inhibition of } \\
\text { parasympathetic nerve activity, and to } \\
\text { improve colonic transit associated with } \\
\text { acute and chronic heterotypic stress. }\end{array}$ & $\begin{array}{l}\text { Fixed position } \\
\text { of abdomen. }\end{array}$ & $\mathrm{EA}, \mathrm{I}-100 \mathrm{~Hz}$ & $\begin{array}{l}\text { Yoshimoto } \\
\text { et al }\end{array}$ \\
\hline
\end{tabular}

the brain. ${ }^{81,82}$ Improved sleep is achieved by electroacupuncture at HT-7 (Shenmen) and SP-6 (Sanyinjiao) acupoints, perhaps due to reduced AMP-activated protein kinase expression, upregulation of acetyl coenzyme A and
$\mathrm{Na}^{+} / \mathrm{K}^{+}$-ATPase levels in paraventricular nucleus, and increased plasma corticosterone levels. ${ }^{83}$ Another possibility is that acupuncture may stabilize the electrical activity of human brains through EEG biofeedback, effectively 
relieving stress and exerting sedative/hypnotic effects. Electroacupuncture at the ST36 (Zusanli) acupoint may prolong sleep times, increasing miR146a expression in sleepdeprived rats, and negatively regulating the Toll-like receptor four signaling pathway. This eventuates in definitive sedative/hypnotic effects and innate immune response regulation. $^{84,85}$ Finally, electroacupuncture at HT7 (Shenmen) and SP6 (Sanyinjiao) is known to enhance local blood circulation, improve cerebral ischemia, and lower plasma norepinephrine and dopamine levels in the rat model of insomnia, further enhancing sleep quality. ${ }^{82}$

\section{Mechanisms of Electroacupuncture in Preventing Postoperative Nausea and Vomiting}

Postoperative nausea and vomiting (PONV) are among the most common adverse effects of anesthesia, affecting up to $30 \%$ of the general population and $80 \%$ of high-risk patients within $24 \mathrm{~h}$ after surgery. ${ }^{86,87}$ Customary treatments of PONV are chiefly pharmaceutical, including 5-HT3 receptor antagonists, NK-1 receptor antagonists, corticosteroids, butyrophenones, antihistamines, anticholinergics, and phenothiazines. ${ }^{88}$ Even at lower doses, antiemetic drugs are not free of side effects, such as QTc interval changes, visual disturbances, dry mouth, and dizziness. ${ }^{89,90}$

According to traditional Chinese medicine, surgery may disturb the balanced states of human bodies, diverting movement of qi and blood. Consequently, gastric qi travels upwards (instead of downwards), producing nausea, vomiting, and constipation. Findings of Lv et al and Alizadeh et al indicate that stimulation at points PC6 (Neiguan) and ST36 (Zusanli) helps reverse the adverse flow of qi, regulating the digestive system and relaxing the gastrointestinal tract. These acupoints have proven effective in preventing nausea and vomiting. Concurrent stimulation at PC6 (Neiguan) and LI4 (Hegu) may permit synergistic regulation of gastrointestinal functions impacted by surgery and anesthetics, preventing PONV and promoting gastrointestinal motility. ${ }^{91,92}$

Gan et al have reported outcomes of a randomized doubleblind controlled study comparing electroacupoint stimulation at PC6 (Neiguan) with ondansetron use for PONV prevention. They analyzed 75 patients facing major breast surgery under general anesthesia. Electroacupoint stimulation surpassed ondansetron in this regard and was met with greater patient satisfaction..$^{93}$ In the context of gastrointestinal surgery, PONV assumes greater importance. ${ }^{94}$ An earlier study of rats has underscored that under normal circumstances, electroacupuncture stimulates distal colonic motility and accelerates colonic transit via the sacral parasympathetic efferent pathway. ${ }^{95}$
Enhancement of the parasympathetic pathway (ie, vagus and pelvic nerves) is therefore essential to speed colonic motility. ${ }^{96}$ Potential mechanisms of electroacupuncture are then as follows: (1) easing of stress via corticotropin-releasing factor (CRF) type-1 receptors to improve colonic transit and mitigation of delayed gastric emptying via CRF type- 2 receptors, thus mediating parasympathetic efferent pathway outflow; ${ }^{97}$ (2) sympathetic inhibition, preventing presynaptic catecholamine blockade of acetylcholine release in parasympathetic nerves $;{ }^{98}$ (3) release of peripheral opioids to relieve pain, curb opioid intake, and combat PONV; ${ }^{99}$ and (4) upregulation of hypothalamic oxytocin (OXT) and parasympathetic nerve inhibition, improving colonic transit hampered by acute and chronic heterotypic stress. ${ }^{100}$

\section{Conclusion}

In conclusion, general anesthesia may degrade postoperative sleep quality and prolong patient recovery times. Targeted use of electroacupuncture may help increase neurotransmitter levels within the body and regulate the biologic clock gene through various means, conferring improved sleep and other benefits. Large-scale, multicenter trials are still needed to confirm these findings.

\section{Funding}

No funding was received for this research.

\section{Disclosure}

The authors report no conflicts of interest in this work.

\section{References}

1. Closs SJ. Patients' night-time pain, analgesic provision and sleep after surgery. Int J Nurs Stud. 1992;29(4):381-392. doi:10.1016/00207489(92)90016-a

2. Krenk L, Jennum P, Kehlet H. Sleep disturbances after fast-track hip and knee arthroplasty. $B r \quad J$ Anaesth. 2012;109(5):769-775. doi:10.1093/bja/aes252

3. Chung F, Liao P, Yegneswaran B, Shapiro CM, Kang W. Postoperative changes in sleep-disordered breathing and sleep architecture in patients with obstructive sleep apnea. Anesthesiology. 2014;120(2):287-298. doi:10.1097/ALN.0000000000000040

4. Chung F, Liao P, Elsaid H, Shapiro CM, Kang W. Factors associated with postoperative exacerbation of sleep-disordered breathing. Anesthesiology. 2014;120(2):299-311. doi:10.1097/ALN.0000000000000041

5. Rosenberg-Adamsen S, Kehlet H, Dodds C, Rosenberg J. Postoperative sleep disturbances: mechanisms and clinical implications. Br J Anaesth. 1996;76(4):552-559. doi:10.1093/bja/76.4.552

6. Dette F, Cassel W, Urban F, et al. Occurrence of rapid eye movement sleep deprivation after surgery under regional anesthesia. Anesth Analg. 2013;116(4):939-943. doi:10.1213/ANE.0b013e3182860e58

7. Selvadurai S, Maynes JT, McDonnell C, et al. Evaluating the effects of general anesthesia on sleep in children undergoing elective surgery: an observational case-control study. Sleep. 2018;41(8):1093-1094. doi:10.1093/sleep/zsy094 
8. Ziqing L, Zhang Y, Wang Y. Electroacupuncture for primary insomnia Protocol for a systematic review and meta-analysis. Medicine. 2018;97:27.

9. Yin X, Gou M, Jian X. Efficacy and safety of acupuncture treatment on primary insomnia: a randomized controlled trial. Sleep Med. 2017;37:193-200. doi:10.1016/j.sleep. 2017.02.012

10. Yang JL, Zhang R, Du L, Yang YS, Liu XC. Clinical observation on the neurotransmitters regulation in patients of insomnia differentiated as yang deficiency pattern treated with warm acupuncture and auricular point sticking therapy. Zhongguo Zhen Jiu. 2014;34 (12): $1165-1168$

11. Liu Z, Chen X, Gao Y, et al. Involvement of GluR2 up-regulation in neuroprotection by electroacupuncture pretreatment via cannabinoid CB1 receptor in mice. Sci Rep. 2015;5:9490. doi:10.1038/ srep09490

12. Jin N, Yang YC, Teng XF, et al. Effect of transcutaneous acupoint electrical stimulation on propofol usage in closed-loop anes- thesia delivery system in pediatric cardiac surgery. Zhongguo Zhong Xi Yi Jie He Za Zhi. 2016;36(8):916-921. In Chinese.

13. Trockel M, Manber R, Chang V, et al. An e-mail delivered CBT for sleep health program for college students: effects on sleep quality and depression symptoms. J Clin Sleep Med. 2011;7:276-281. doi:10.5664/JCSM.1072

14. Wichniak A, Jankowski KS, Skalski M, et al. Treatment guidelines for circadian rhythm sleep-wake disorders of the polish sleep research society and the section of biological psychiatry of the polish psychiatric association. Part I. Physiology, assessment, and therapeutic methods. Psychiatr Pol. 2017;51(5):793-814. doi:10.12740/PP/OnlineFirst/66810

15. Teoh AYB, Chong CCN, Leung WW, et al. Electroacupuncturereduced sedative and analgesic requirements for diagnostic EUS: a prospective, randomized, double-blinded, sham-controlled study. Gastrointest Endosc. 2018;87(2):476-485. doi:10.1016/j.gie.2017. 07.029

16. Franks NP. General anaesthesia: from molecular targets to neuronal pathways of sleep and arousal. Nat Rev Neurosci. 2008;9 (5):370-386. doi:10.1038/nrn2372

17. Szymusiak R, Alam N, Steininger TL, McGinty D. Sleep-waking discharge patterns of ventrolateral preoptic/anterior hypothalamic neurons in rats. Brain Res. 1998;803(1-2):178-188. doi:10.1016/ s0006-8993(98)00631-3

18. Prys-Roberts C. Anaesthesia: a practical or impractical construct? Br J Anaesth. 1987;59(11):1341-1345. doi:10.1093/bja/59.11.1341

19. Miller RD. Miller's Anesthesia. 7th ed. Churchill Livingstone Elsevier; 2010.

20. Björnström K, Eintrei C. The difference between sleep and anaesthesia is in the intracellular signal: propofol and GABA use different subtypes of the GABA(A) receptor beta subunit and vary in their interaction with actin. Acta Anaesthesiol Scand. 2003;47 (2):157-164. doi:10.1034/j.1399-6576.2003.00007.x

21. Yuan J, Yu T. The mechanisms of general anesthesia and ventrolateral preoptic nucleus sleep pathway. Int J Anesth Resus. 2015;36 (3):283-286

22. Franks NP, Zecharia AY. Sleep and general anesthesia. Can $J$ Anaesth. 2011;58(2):139-148. doi:10.1007/s12630-010-94 20-3

23. Nelson LE, Guo TZ, Lu J, Saper CB, Franks NP, Maze M. The sedative component of anesthesia is mediated by GABA(A) receptors in an endogenous sleep pathway. Nat Neurosci. 2002;5 (10):979-984. doi:10.1038/nn913

24. Xia Y, Ciu Y, Chu SS, et al. Murine clock gene express in the suprachiasmatic nuclei and peripheral blood mononuclear cells during the daily sleep-wake rhythm and after isoflurane anesthesia. Sleep Biol Rhythm. 2015;13:357-365. doi:10.1111/ sbr. 12126
25. Buhr ED, Takahashi JS. Molecular components of the Mammalian circadian clock. Handb Exp Pharmacol. 2013;217:3-27. doi:10.1007/978-3-642-25950-0_1.

26. Knill RL, Moote CA, Skinner MI, Rose EA. Anesthesia with abdominal surgery leads to intense REM sleep during the first postoperative week. Anesthesiology. 1990;73:52-61. doi:10.1097/ 00000542-199007000-00009

27. Pick J, Chen Y, Moore JT, et al. Rapid eye movement sleep debt accrues in mice exposed to volatile anesthetics. Anesthesiology. 2011;115(4):702-712. doi:10.1097/ALN.0b0 $13 \mathrm{e} 31822 \mathrm{ddd} 72$

28. Opperer M, Gerner P, Memtsoudis SG. Additives to local anesthetics for peripheral nerve blocks or local anesthesia: a review of the literature. Pain Manag. 2015;5(2):117-128. doi:10.2217/ pmt. 15.2

29. Cronin A, Keifer J, Davies M, King T, Bixler E. Melatonin secretion after surgery. Lancet. 2000;356:1244-1245. doi:10.1016/ S0140-6736(00)02795-1

30. Guo XY, Luo AL, Ren HZ, Yie TH, Huang YG. Perioperative melatonin secretion rhythm in patients undergoing coronary artery bypass grafting surgery. Zhongguo Yi Хие Ке Хие Yuan Хие Ваo. 2003;25(5):594-598.

31. Artemiou P, Bily B, Bilecova-Rabajdova M, et al. Melatonin treatment in the prevention of postoperative delirium in cardiac surgery patients. Kardiochir Torakochirurgia Pol. 2015;12(2):126-133. doi:10.5114/kitp.2015.52853

32. Xie Z, Chen F, Li WA, et al. A review of sleep disorders and melatonin. Neurol Res. 2017;39(6):559-565. doi:10.1080/ 01616412.2017.1315864

33. Fan Y, Yuan L, Ji M, Yang J, Gao D. The effect of melatonin on early postoperative cognitive decline in elderly patients undergoing hip arthroplasty: a randomized controlled trial. J Clin Anesth. 2017;39:77-81. doi:10.1016/j.jclinane.2017.03.023

34. Fadayomi AB, Ibala R, Bilotta F, Westover MB, Akeju O. A systematic review and meta-analysis examining the impact of sleep disturbance on postoperative delirium. Crit Care Med. 2018;46(12):e1204-e1212. doi:10.1097/CCM.0000000000003400

35. Zhao Y, Zhang Y, Yang Z, et al. Sleep disorders and cognitive impairment in peritoneal dialysis: a multicenter prospective cohort study. Kidney Blood Press Res. 2019;44(5):1115-1127. doi:10. $1159 / 000502355$

36. Barger LK, Rajaratnam SMW, Cannon CP, et al. Short sleep duration, obstructive sleep apnea, shiftwork, and the risk of adverse cardiovascular events in patients after an acute coronary syndrome. $J$ Am Heart Assoc. 2017;6(10):e006959. doi:10.1161/JAHA. 117.006959

37. Haack M, Simpson N, Sethna N, Kaur S, Mullington J. Sleep deficiency and chronic pain: potential underlying mechanisms and clinical implications. Neuropsychopharmacology. 2020;45 (1):205-216. doi:10.1038/s41386-019-0439-z

38. Wright KP Jr, Drake AL, Frey DJ, et al. Influence of sleep deprivation and circadian misalignment on cortisol, inflammatory markers, and cytokine balance. Brain Behav Immun. 2015;47:24-34. doi:10.1016/j.bbi.2015.01.004

39. Cordeira J, Kolluru SS, Rosenblatt H, Kry J, Strecker RE, McCarley RW. Learning and memory are impaired in the object recognition task during metestrus/diestrus and after sleep deprivation. Behav Brain Res. 2018;339:124-129. doi:10.1016/j. bbr.2017.11.033

40. Wertz AT, Ronda JM, Czeisler CA, Wright KP Jr. Effects of sleep inertia on cognition. JAMA. 2006;295(2):163-164. doi:10.1001/ jama.295.2.163

41. Gögenur I, Middleton B, Burgdorf S, et al. Impact of sleep and circadian disturbances in urinary 6-sulphatoxymelatonin levels, on cognitive function after major surgery. $J$ Pineal Res. 2007;43:179-184. doi:10.1111/j.1600-079X.2007.00460.x 
42. Lene $\mathrm{K}$, Henrik K, Torben BH, et al. Cognitive dysfunction after fast-track hip and knee replacement. Neurosci Anesthesiol Perioperative Med. 2014;5(118):1034-1040.

43. Kapsimalis F, Richardson G, Opp MR, et al. Cytokines and normal sleep. Curr Opin Pulm Med. 2005;11:481-484. doi:10.1097/01. mcp.0000183062.98665.6b

44. Spath-Schwalbe E, Hansen K, Schmidt F, et al. Acute effects of recombinant human interleukin- 6 on endocrine and central nervous sleep functions in healthy men. $J$ Clin Endocrinol Metab. 1998;83:1573-1579. doi:10.1210/jcem.83.5.4795

45. Wright CB, Sacco RL, Rundek TR, et al. Interleukin-6 is associated with cognitive function: the Northern Manhattan Study. J Stroke Cerebrovasc Dis. 2006;15:34-38. doi:10.1016/j.jstrokecerebrovasdis. 2005.08.009

46. Lynch MA. Age-related impairment in long-term potentiation in hippocampus: a role for the cytokine, interleukin-1 beta? Prog Neurobiol. 1998;56:571-589. doi:10.1016/S0301-0082(98)00 054-9

47. Cedernaes J, Osler ME, Voisin S, et al. Acute sleep loss induces tissue-specific epigenetic and transcriptional alterations to circadian clock genes in men. J Clin Endocrinol Metab. 2015;100(9):E1255E1261. doi:10.1210/JC.2015-2284

48. Hou J, Shen Q, Wan X, Zhao B, Wu Y, Xia Z. REM sleep deprivation-induced circadian clock gene abnormalities participate in hippocampal-dependent memory impairment by enhancing inflammation in rats undergoing sevoflurane inhalation. Behav Brain Res. 2019;364:167-176. doi:10.1016/j.bbr.2019.01.038

49. Takase B, Akima T, Uehata A, Ohsuzu F, Kurita A. Effect of chronic stress and sleep deprivation on both flow-mediated dilation in the brachial artery and the intracellular magnesium level in humans. Clin Cardiol. 2004;27(4):223-227. doi:10.1002/clc.49 60270411

50. Slutsky I, Abumaria N, Wu LJ, et al. Enhancement of learning and memory by elevating brain magnesium. Neuron. 2010;65 (2):165-177. doi:10.1016/j.neuron.2009.12.026

51. Fassbender P, Herbstreit F, Eikermann M, Teschler H, Peters J. Obstructive sleep apnea-a perioperative risk factor. Dtsch Arztebl Int. 2016;113(27-28):463-469. doi:10.3238/arztebl.2016.0463

52. Fernandes NM, Nield LE, Popel N, et al. Symptoms of disturbed sleep predict major adverse cardiac events after percutaneous coronary intervention. Can $J$ Cardiol. 2014;30(1):118-124. doi:10.1016/j.cjca.2013.07.009

53. Durgan DJ, Young ME. The cardiomyocyte circadian clock: emerging roles in health and disease. Circ Res. 2010;106(4):647-658. doi:10.1161/CIRCRESAHA.109.209957

54. Takeda N, Maemura K. The role of clock genes and circadian rhythm in the development of cardiovascular diseases. Cell Mol Life Sci. 2015;72(17):3225-3234. doi:10.1007/s00018-015-1923-1

55. Durgan DJ, Pulinilkunnil T, Villegas-Montoya C, et al. Short communication: ischemia/reperfusion tolerance is time-of-daydependent: mediation by the cardiomyocyte circadian clock. Circ Res. 2010;106(3):546-550. doi:10.1161/CIRCRESAHA.109.209 346

56. Ohe Y, Iijima N, Kadota K, Sakamoto A, Ozawa H. The general anesthetic sevoflurane affects the expression of clock gene mPer2 accompanying the change of NAD+ level in the suprachiasmatic nucleus of mice. Neurosci Lett. 2011;490(3):231-236. doi:10.1016/ j.neulet.2010.12.059

57. Viswambharan H, Carvas JM, Antic V, et al. Mutation of the circadian clock gene Per2 alters vascular endothelial function. Circulation. 2007;115(16):2188-2195. doi:10.1161/CIRCULATIONAHA.106. 653303

58. Ma B, Chen J, Mu Y, et al. Proteomic analysis of rat serum revealed the effects of chronic sleep deprivation on metabolic, cardiovascular and nervous system. PLoS One. 2018;13(9): e0199237. doi:10.1371/journal.pone.0199237
59. Wu MS, Chen KH, Chen IF, et al. The efficacy of acupuncture in post-operative pain management: a systematic review and meta-analysis. PLoS One. 2016;11(3):e0150367. doi:10.1371/journal.pone. 0150367

60. Weschenfelder J, Sander C, Kluge M, Kirkby KC, Himmerich H. The influence of cytokines on wakefulness regulation: clinical relevance, mechanisms and methodological problems. Psychiatr Danub. 2012;24(2):112-126.

61. Qiao LN, Gao QL, Tan LH, et al. Electroacupuncture of multiple acupoints is significantly superior to that of single acupoint in improving sleep by regulating serum sleep-promoting and awakening-promoting factors in insomnia rats. Zhen Ci Yan Jiu. 2018;43(10):651-656. doi:10.13702/j.1000-0607.180317

62. Sun Y, Gan TJ, Dubose JW, Habib AS. Acupuncture and related techniques for postoperative pain: a systematic review of randomized controlled trials. $\mathrm{Br} J$ Anaesth. 2008;101(2):151-160. doi:10.1093/bja/aen146

63. Chouchou F, Khoury S, Chauny JM, Denis R, Lavigne GJ. Postoperative sleep disruptions: a potential catalyst of acute pain? Sleep Med Rev. 2014;18(3):273-282. doi:10.1016/j.smrv.2013.07.002

64. Dimsdale JE, Norman D, DeJardin D, Wallace MS. The effect of opioids on sleep architecture. J Clin Sleep Med. 2007;3(1):33-36.

65. Shaw IR, Lavigne G, Mayer P, Choinière M. Acute intravenous administration of morphine perturbs sleep architecture in healthy pain-free young adults: a preliminary study. Sleep. 2005;28 (6):677-682. doi:10.1093/sleep/28.6.677

66. Liu S, Wang B, Li S, et al. Immune cell populations decrease during craniotomy under general anesthesia. Anesth Analg. 2011;113(3):572-577. doi:10.1213/ANE.0b013e3182278237

67. Sim CK, Xu PC, Pua HL, Zhang G, Lee TL. Effects of electroacupuncture on intraoperative and postoperative analgesic requirement. Acupunct Med. 2002;20(2-3):56-65. doi:10.1136/ aim.20.2-3.56

68. Zeng K, Dong HJ, Chen HY, Chen Z, Li B, Zhou QH. Wrist-ankle acupuncture for pain after transcatheter arterial chemoembolization in patients with liver cancer: a randomized controlled trial. $\mathrm{Am}$ $J$ Chin Med. 2014;42(2):289-302. doi:10.1142/S0192415X14 500190

69. White A, Cummings TM, Filshie J. An Introduction to Western Medical Acupuncture. Churchill Livingstone/Elsevier; 2008.

70. Mayor DF. Electroacupuncture: A Practical Manual and Resource. Elsevier Churchill Livingstone; 2007.

71. Qiao LN, Wang JY, Liu JL, et al. Effects of electroacupuncture Futu acupoint on expression of spinal cord pain-sensitive substance $\mathrm{P}$ and analgesic substance 5-HT 1A receptor in rats with cervical incision pain. Acupunct Res. 2010;235(2):91-98.

72. Anand P, Whiteside G, Fowler CJ, Hohmann AG. Targeting CB2 receptors and the endocannabinoid system for the treatment of pain. Brain Res Rev. 2009;60:255-266. doi:10.1016/j.brainresrev. 2008.12.003

73. Qiao LN, Yang YS, Liu JL, et al. Effects of electroacupuncture at Futu on mRNA expression of 5-HT 1A and 5-HT 2A receptors in cervical spinal cord in rats with cervical incision pain. Acupuncture. 2011;36(6):391-394. In Chinese.

74. Gao YH, Chen SP, Liu JL, et al. Effects of electroacupuncture on pain behavior response in rats with inflammatory pain in thyroid region and expression and phosphorylation levels of N-methylD-aspartic acid receptor subtype NR2B in spinal cord. Acupunct Study. 2009;34(6):376-379. In Chinese.

75. Elliott R, McKinley S, Cistulli P. The quality and duration of sleep in the intensive care setting: an integrative review. Int J Nurs Stud. 2011;48(3):384-400. doi:10.1016/j.ijnurstu.2010.11.006

76. Ye WJ, Huang LQ, Zheng LF, et al. Chinese medicine point massage has effect on sleep quality and shoulder joint function in postoperative breast cancer. Xin Zhong Yi. 2020;52(06):161-163. In Chinese. 
77. Xiao XL, Liu ZS. Efficacy evaluation of electroacupuncture therapy for insomnia at different times. Acupunct Res. 2008;33 (3):201-204. In Chinese.

78. Xia WM, Lin WQ, Chen CC. Effects of moxibustion at Baihui acupoint on negative mood and sleep quality of patients after thyroid cancer surgery. Nurs Res. 2019;13:2239-2242. In Chinese.

79. Qin Y. Clinical study on the effect of intradermal needle therapy on sleep quality of patients with total hysterectomy. Guangzhou Univ Trad Chin Med. 2018. In Chinese.

80. Huang QH. The intervention Study of auricular point therapy on the Sleep quality of patients with hysterectomy in early convalescence. Guangzhou Univ Trad Chin Med. 2016. In Chinese.

81. Tang L, You F, Hu X, Li YF. Electroacupuncture improves insomnia by down-regulating peripheral benzodiazepine receptor expression in hippocampus, and up-regulating 5-HT, 5-HIAA, TNF- $\alpha$ and IL-1 $\beta$ contents in hypothalamus in insomnia rats. Zhen Ci Yan Jiu. 2019;44(8):560-565. doi:10.13702/j.1000-0607.180610

82. Cheng C, Liu P, Wu Q, et al. Effects of electroacupuncture on anxiety and sympathetic-adrenal medulla system in rats with insomnia. Zhongguo Zhen Jiu. 2015;35(9):923-926.

83. Zhu YH, Yang CH, He LX, Qiao L, Cheng CS. Effect of Electroacupuncture at "Shenmen"(HT7) and "Sanyinjiao"(SP6) on Energy Metabolism in Paraventricular Nucleus of Hypothalamus of Insomnia Rats. Zhen Ci Yan Jiu. 2019;44(3):170-175. doi:10. 13702/j.1000-0607.170996

84. Yang J, Shang B, Shi H, Zhu S, Lu G, Dai F. The role of toll-like receptor 4 and mast cell in the ameliorating effect of electroacupuncture on visceral hypersensitivity in rats. Neurogastroenterol Motil. 2019;31(6):e13583. doi:10.1111/nmo.13583

85. Brianza-Padilla M, Sánchez-Muñoz F, Vázquez-Palacios G, et al. Cytokine and microRNA levels during different periods of paradoxical sleep deprivation and sleep recovery in rats. PeerJ. 2018;6: e5567. doi:10.7717/peerj.5567

86. Gan TJ, Habib AS, Miller TE, White W, Apfelbaum JL. Incidence, patient satisfaction, and perceptions of post-surgical pain: results from a US national survey. Curr Med Res Opin. 2014;30:149-160. doi:10.1185/03007995.2013.860019

87. Son J, Yoon H. Factors affecting postoperative nausea and vomiting in surgical patients. $J$ Perisanesth Nurs. 2018;33:461-470. doi:10.1016/j.jopan.2016.02.012

88. Shin HC, Kim JS, Lee SK, et al. The effect of acupuncture on postoperative nausea and vomiting after pediatric tonsillectomy: a meta-analysis and systematic review. Laryngoscope. 2016;126 (8):1761-1767. doi:10.1002/lary.25883

89. Gan TJ, Diemunsch P, Habib AS, et al. Consensus guidelines for the management of postoperative nausea and vomiting. Anesth Analg. 2014;118(1):85-113. doi:10.1213/ANE.0000000000000002
90. Lee A, Fan LT. Stimulation of the wrist acupuncture point P6 for preventing postoperative nausea and vomiting. Cochrane Database Syst Rev. 2009;2:CD003281. doi:10.1002/14651858.CD003281. pub3

91. Lv JQ, Feng RZ, Li N. P6 acupoint stimulation for prevention of postoperative nausea and vomiting in patients undergoing craniotomy: study protocol for a randomized controlled trial. Trials. 2013;14:153. doi:10.1186/1745-6215-14-153

92. Alizadeh R, Esmaeili S, Shoar S, Bagheri-Hariri S, Shoar N. Acupuncture in preventing postoperative nausea and vomiting: efficacy of two acupuncture points versus a single one. $J$ Acupunct Meridian Stud. 2014;7(2):71-75. doi:10.1016/j. jams.2013.04.005

93. Gan TJ, Jiao KR, Zenn M, Georgiade G. A randomized controlled comparison of electro-acupoint stimulation or ondansetron versus placebo for the prevention of postoperative nausea and vomiting. Anesth Analg. 2004;99(4):1070-1075. doi:10.1213/01.ANE.000 $0130355.91214 .9 \mathrm{E}$

94. Cheong KB, Zhang JP, Huang Y, Zhang ZJ. The effectiveness of acupuncture in prevention and treatment of postoperative nausea and vomiting-a systematic review and meta-analysis. PLoS One. 2013;8(12):e82474. doi:10.1371/journal.pone.0082474

95. Iwa M, Matsushima M, Nakade Y, Pappas TN, Fujimiya M, Takahashi T. Electroacupuncture at ST-36 accelerates colonic motility and transit in freely moving conscious rats. Am J Physiol Gastrointest Liver Physiol. 2006;290(2):G285-G292. doi:10.1152/ ajpgi.00068.2005

96. Tong WD, Ridolfi TJ, Kosinski L, Ludwig K, Takahashi T. Effects of autonomic nerve stimulation on colorectal motility in rats. Neurogastroenterol Motil. 2010;22(6):688-693. doi:10.1111/ j.1365-2982.2009.01461.x

97. Takahashi T. Mechanism of acupuncture on neuromodulation in the gut-a review. Neuromodulation. 2011;14(1):8-12. doi:10.1111/ j.1525-1403.2010.00295.x

98. Sanders KM, Koh SD, Ro S, Ward SM. Regulation of gastrointestinal motility-insights from smooth muscle biology. Nat Rev Gastroenterol Hepatol. 2012;9(11):633-645. doi:10.1038/ nrgastro.2012.168

99. Fukuda H, Suenaga K, Tsuchida D, et al. The selective mu opioid receptor antagonist, alvimopan, improves delayed GI transit of postoperative ileus in rats. Brain Res. 2006;1102(1):63-70. doi:10.1016/j.brainres.2006.02.092

100. Yoshimoto S, Babygirija R, Dobner A, Ludwig K, Takahashi T. Anti-stress effects of transcutaneous electrical nerve stimulation (TENS) on colonic motility in rats. Dig Dis Sci. 2012;57 (5):1213-1221. doi:10.1007/s10620-012-2040-8

\section{Publish your work in this journal}

Nature and Science of Sleep is an international, peer-reviewed, open access journal covering all aspects of sleep science and sleep medicine, including the neurophysiology and functions of sleep, the genetics of sleep, sleep and society, biological rhythms, dreaming, sleep disorders and therapy, and strategies to optimize healthy sleep.
The manuscript management system is completely online and includes a very quick and fair peer-review system, which is all easy to use. Visit http://www.dovepress.com/testimonials.php to read real quotes from published authors. 